\title{
Bersyukur dan Resiliensi Akademik Mahasiswa
}

\author{
Lufiana Harnany Utami \\ UIN Sunan Gunung Djati Bandung Jl. A.H Nasution No. 105 Bandung \\ Lufiana.harnany@uinsgdbdg
}

\begin{abstract}
Resiliensi akademik adalah kemampuan menghadapi tantangan, kesulitan, dan tekanan dalam seting akademik. Penerapan sistem keyakinan dan tradisi yang ada dalam budaya dan agama merupakan salah satu hal yang disarankan untuk pembentukan resiliensi. Bersyukur merupakan tradisi yang disarankan dalam agama untuk dapat menjalani hidup dengan positif. Penelitian ini melihat hubungan bersyukur dengan resiliensi akademik pada mahasiswa UIN Sunan Gunung Djati. Penelitian kuantitatif dengan desain korelasional melibatkan 400 mahasiswa untuk mendapatkan data bersyukur dan resiliensi. Instrumen pengukuran yang digunakan adalah The Gratitude Questionnaire-6 yang dikembangkan oleh McCullough, Emmons, \& Tsang (2002) dan skala resiliensi Connor-Davidson Resilience Scale (CD-RISC) yang dikembangkan oleh Connor dan Davidson (2003). Teknik analisis data yang digunakan adalah uji regresi linier sederhana. Hasil penelitian menunjukkan bahwa bersyukur memiliki kontribusi terhadap pembentukan resiliensi akademik pada mahasiswa UIN Sunan Gunung Djati Bandung. Saran bagi penelitian berikutnya dapat menggunakan variabel lain untuk perluasan kajian tentang resiliensi.
\end{abstract}

\section{Keywords: resiliensi akademik, bersyukur, mahasiswa}

\section{PENDAHULUAN}

Mahasiswa memiliki pengalaman yang berbeda-beda dalam menghadapi kehidupan akademik di perguruan tinggi dengan berbagai masalah dan kesulitan yang dihadapi. Fenomena yang terlihat di perguruan tinggi adalah sejumlah mahasiswa dapat melalui serta mencapai berbagai tahapan dengan baik namun ada pula yang gagal menjalaninya. Morales dan Trotman (2004) mengatakan bahwa setiap individu mahasiswa menghadapi masalah dan kesulitan yang berbeda dalam kehidupan akademik. Sejumlah penelitian yang dilakukan pada populasi mahasiswa di America (Dyson \& Renk, 2006), Canada (Struthers, Perry \& Menec, 2000), China (Tao, Dong, Pratt, Hunsberger \& Pancer, 2000), Australia (Stallman, 2010), dan Inggris (Wilcox, Winn \& Fyvie-Gauld, 2005) menyoroti banyaknya tuntutan dan tantangan di perguruan tinggi seperti belajar, menghadapi ujian, pembentukan identitas, dan kemandirian dari orangtua mempengaruhi fungsi sosial, emosi, fisik, dan akademik mahasiswa. Mereka menemukan bahwa lingkaran "disruption" dan "reintegration", dianggap sebagai proses resiliensi.

Resiliensi bukan trait yang tidak bisa berubah karena itu adalah proses yang dinamis dan melibatkan adaptasi positif dalam menghadapi tantangan dan kesulitan dalam hidup (Smith, 1999). Selain itu resiliensi juga dinilai sebagai kondisi multidimensi sehingga bisa jadi individu berbeda kemampuannya dalam menghadapi bentuk kesulitan yang sama (Taylor, 2000). Setiap individu terlahir dengan kemampuan resiliensi yang dimiliki sehingga resiliensi bukanlah sesuatu yang spektaluler karena itu adalah proses yang dialami setiap individu (Richardson dan Waite, 2002). Benard (2007) menambahkan bahwa 70\% pemuda 
yang hidup dalam kesulitan terbiasa untuk menghadapi kesulitan, mengembangkan kemampuan dan ketrampilannya menghadapi hidup.

Masten, Best, dan Garmezy (1990) menggambarkan tiga karakteristik resiliensi yaitu kemampuan individu menghadapi masalah dan beradaptasi dengan kondisi yang tidak menyenangkan, kemampuan beradaptasi dengan dirinya sendiri menghadapi pengalaman hidup yang menekan dan kemampuan menghadapi kondisi yang pernah menimbulkan trauma seperti bencana alam, kematian orang dekat atau pengalaman mengalami kecelakaan. Hanewald's (2011) menjabarkan tiga bentuk resiliensi yaitu (1) "overcoming the odds" yang menggambarkan kekuatan personal individu menghadapi kesulitan, (2) "coping" kemampuan menghadapi berbagai bentuk resiko negatif, dan (3) "recovery from trauma" adalah kemampuan untuk kembali bangkit dari kesulitan atau keterpurukan.

Connor dan Davidson (2003) menambahkan bahwa individu yang resilien tidak hanya mampu menghadapi kesulitan yang dihadapi tetapi juga dapat beradaptasi secara positif dengan kejadian-kejadian yang negatif. Secara psikologis resiliensi adalah kecenderungan untuk dapat menghadapi stress dan kondisi sulit (Masten, 2009). Wolin dan Wolin (1993) mengatakan bahwa kekuatan dapat muncul setelah menghadapi kesulitan. Kesulitan memang dapat melemahkan atau menguatkan individu tergantung bagaimana dia memanfaatkan kondisi sulit tersebut. Jika memang kesulitan itu menyakitkan akan mendorong individu tidak mampu melanjutkan kehidupannya yang sehat. Namun jika mereka mampu menghadapinya dengan baik maka kesulitan itu akan dapat menjadi kesempatan atau tantangan yang membuatnya menjadi lebih kuat dan mendapatkan banyak kemampuan lainnya.

Menurut Masten dan Reed (2002) resiliensi telah banyak diteliti sebagai kemampuan individu untuk beradaptasi, menghadapi stress, dan menghadapi kondisi sulit. Winter dan Yaffe (2000) dalam penelitian yang dilakukan pada 408 mahasiswa semester satu menunjukkan adanya tingkat depresi yang signifikan pada akhir tahun ajaran pertama. Memasuki dunia perguruan tinggi akan memicu proses resiliensi akademik dimana mahasiswa akan mengalami intensitas kekacauan emosi yang disebut "disruption". Namun mahasiswa juga akan mengalami tahap "reintegration" setelah tahap disruption dimana akhirnya mahasiswa dapat menyesuaikan diri, berhasil melalui segala bentuk ujian, pembentukan identitas diri, dan mencapai kemandirian dalam memberdayakan fungsi sosial, emosional, fisik dan akademik (Pancer, Pratt \& H unsberger, 2000).

Resiliensi secara akademik dalam konteks perguruan tinggi diartikan sebagai kemampuan menghadapi tantangan, kesulitan, dan tekanan dalam seting akademik secara efektif (Martin \& Marsh, 2006). Ada sejumlah faktor resiko yang harus dihadapi mahasiswa seperti nilai yang rendah, mengejar batas waktu yang telah ditentukan, tugas yang sulit, absensi yang ketat, serta kewajiban mengikuti sejumlah kelas perkuliahan (Martin \& Marsh, 2006). Singkatnya resiliensi akademik mengacu pada fenomena yang digambarkan dengan kemampuan mencapai hasil yang baik meskipun berhadapan dengan kesulitan dalam berdaptasi dan mengikuti perkembangan akademik.

Menurut Wang dan Gordon (1994) pembelajar yang memiliki resiliensi akademik mampu mengubah lingkungan yang dianggap sulit menjadi sumber motivasi dengan tetap 
mempertahankan harapan dan aspirasi yang tinggi, berorientasi pada tujuan, memiliki ketrampilan dalam memecahkan masalah, serta memiliki kompetensi secara sosial. Alva (1991) menambahkan bahwa individu yang memiliki resiliensi akademik dapat berhasil mencapai keberhasilan dalam proses pendidikan yang dijalani dimana mereka berjuang dalam situasi yang negatif dan tetap memiliki kemungkinan tidak berhasil.

Menurut Morales (2008) resiliensi akademik dipengaruhi oleh keyakinan yang dimiliki mahasiswa tentang dirinya, orang lain dan dunia sekitarnya sehingga resiliensi itu berangkat dari kesehatan mental yang dialami mahasiswa. Rickinson (1997) juga menambahkan bahwa ketrampilan coping yang dimiliki mahasiswa dapat meningkatkan resiliensinya, motivasi dan persistensinya sampai dia dapat menyelesaikan masa studinya.

Martin dan Marsh (2009) melakukan penelitian tentang resiliensi akademik pada dimensi psikologi yang lebih luas dan menemukan lima faktor yang dapat memprediksi relisiensi akademik yaitu self-efficacy, kontrol diri, perencanaan, kecemasan yang rendah, serta kegigihan. Jika ingin membuat intervensi pada resiliensi mahasiswa maka kelima faktor tersebut harus dilibatkan dan dipertimbangkan dalam merancang materinya. Dass-Brailsford, (2005) dalam penelitiannya pada pemuda Afrika selatan yang memiliki resiliensi akademik yang tinggi serta berhasil mencapai keberhasilan akademik menunjukkan bahwa kemiskinan keluarga memang menjadi faktor resiko mereka namun dukungan dari keluarga yang didapat, karakteristik keluarga serta role mode dan dukungan dari sekolah tetap mereka dapatkan. Mereka memiliki self-esteem yang tinggi, motivasi yang tinggi serta punya orientasi pada tujuan. Selain itu mereka mereka menjadikan guru mereka sebagai role model dan sumber semangat. Keyakinan yang tertanam pada mereka adalah kekuatan yang tinggi akan memberikan kenyamanan pada hidup mereka nantinya di masa depan.

Brown, \& Benard (2001) juga mengatakan bahwa dukungan lingkungan kampus berhubungan dengan resiliensi siswa. Keterlibatan dalam kegiatan akademik, pandangan positif terhadap sekolah, serta self-esteem yang tinggi adalah faktor yang membentuk resiliensi akademik mahasiswa. Wasonga, Christman dan Kilmer (2003) membandingkan antara mahasiswa yang memiliki resiliensi akademik dan yang tidak. Hasil penelitiannya menunjukkan bahwa mereka yang memiliki resiliensi tinggi adalah mereka dengan persepsi tinggi terhadap motivasi prestasi, kepuasan diri, keterlibatan, serta konsep diri tentang akademik. Gonzales dan Padilla (1997) mengatakan bahwa rasa memiliki menjadi prediktor yang signifikan terhadap resiliensi akademik sehingga itu mendukung teori yang mengatakan bahwa mahasiswa yang terlibat dalam berbagai kegiatan akademik dan memiliki hubungan positif dengan lingkungan kampus akan memiliki resiliensi akademik yang lebih besar.

Bernard (1991) menyarankan upaya yang dapat dilakukan institusi akademik untuk menyediakan kesempatan bagi mahasiswa dalam mengembangkan aset internal untuk dapat memiliki resiliensi. Bernard (1991) menegaskan bahwa mengajarkan ketrampilan untuk menyelesaikan masalah akan membuat mahasiswa memiliki resiliensi dan mampu mengatasi situasi sulit yang dihadapi yang akan membentuk pribadi mandiri yang tentunya nanti akan mengarahkan mereka menjadi produktif dan sukses dalam hidup. McMillan dan Reed (1994) mengidentifikasi sejumlah upaya yang dilalui mahasiswa yang terukur memiliki resiliensi akademik yang tinggi yaitu adanya keterlibatan dalam program intervensi, sibuk dengan berbagai kegiatan untuk menggunakan waktu secara positif di perguruan tinggi. Memiliki 
tujuan yang jelas dan untuk jangka waktu pendek dan panjang, optimis tentang hidup serta punya keyakinan untuk dapat mencapai apa yang dituju tentunya mengalami berbagai kesulitan dan kendala semua itu membentuk resiliensi akademik mahasiswa selama mereka berada dalam lingkungan perguruan tinggi.

McMillan dan Reed (1994) menambahkan sejumlah karakter mahasiswa yang memiliki resiliensi akademik yaitu memiliki kendala internal yang kuat tentang hidupnya dan memiliki tanggung jawab personal terhadap tindakan yang diambil. Mereka juga memiliki role model yang diyakini baik untuk diikuti. Pentingnya akademik resiliensi digambarkan oleh Finn dan Rock (1997) bahwa akademik resiliensi sangat penting dalam keberhasilan akademik mahasiswa. Mahasiswa yang memiliki keterlibatan dalam kegiatan kampus dan merasa lebih memiliki hubungan dengan lingkungan kampus terlihat lebih memiliki resiliensi akademik. Smokowski (1999) menambahkan bahwa keterlibatan akademik dan keterlibatan sosial adalah aspek penting dalam pembentuakan resiliensi akademik mahasiswa. Mahasiswa yang memiliki resiliensi akademik mampu menterjemahkan lingkungan yang sulit menjadi sumber motivasi dengan tetap mempertahankan harapan dan aspirasi yang tinggi, memiliki orientasi tujuan yang jelas, memiliki ketrampilan menyelesaikan masalah yang baik, serta memiliki kompetensi berhubungan sosial dengan berbagai pihak.

Finn dan Rock (1997) menggambarkan mahasiswa yang memiliki resiliensi akademik lebih suka bekerja keras, jarang meninggalkan kelas, dan jarang mengalami masalah dalam kelas. Wolin dan Wolin (1993) menambahkan karakteristik resiliensi akademik lainnya yaitu memiliki wawasan, mandiri, kreatif, memiliki selera humor, dan punya inisiatif. Singkatnya resiliensi akademik dipengaruhi oleh sejumlah faktor pendukung yang itu akan menjadi kunci keberhasilan mahaisiswa melewati tahapan akademik di perguruan tinggi.

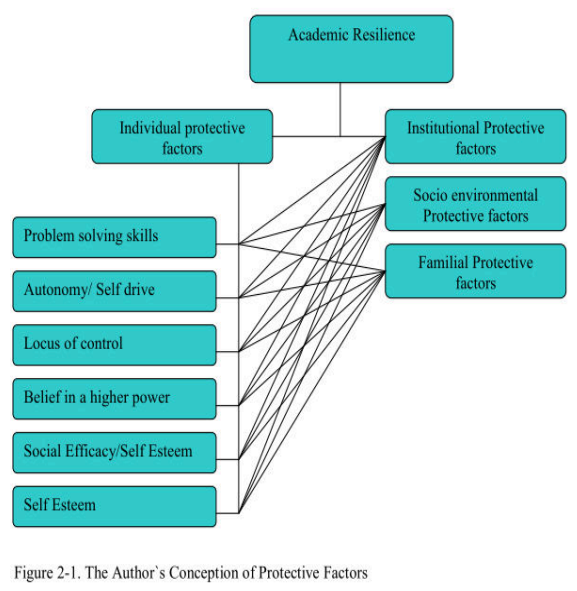

Gambar 1. Faktor Pendukung Resiliensi pada Mahasiswa

Gambar 1 menunjukkan sejumlah faktor pendukung resiliensi yang dapat dimiliki oleh individu mahasiswa. Faktor pendukung pertama adalah faktor dari dalam diri individu. Benard (2004) mengatakan bahwa setiap individu memiliki resiliensi dalam diri yang dibawa secara genetik dan itu bisa terungkap secara alami dengan adanya sejumlah atribut di lingkungan tempat mereka berada. Sejumlah faktor pendukung yang sifatnya personal adalah ketrampilan memecahkan masalah, kemandirian, self-efficacy, kemampuan sosial, internal 
locus of control tingkatan yang tinggi dalam keterlibatan semua itu dianggap karakteristik individu yang memiliki resiliensi akademik. Ketrampilan menyelesaikan masalah mencakup ketrampilan membuat rencana dan mengolah sejumlah alternatif solusi dalam keadaan yang sulit serta berpikir secara kritis, kreatif, dan reflektif. Kemandirian menunjukan bahwa mahasiswa memiliki kemampuan mengendalikan diri, mandiri mengambil keputusan serta memiliki keyakinan positif terhadap masa depan.

Selain itu mahasiswa juga memiliki otonomi, mereka percaya pada kemampuannya untuk mempengaruhi kondisi sekitar mereka (Bernard, 1993). Mahasiswa yang memiliki kompetensi sosial yang baik tentunya memiliki kemampuan berinteraksi dan mengakomodasi hal-hal yang dibutuhkan dalam komunitas kampus. Kemampuan lainnya yang juga menjadi faktor pendukung personal adalah daya toleransi terhadap pengaruh negatif yang ada, selfesteem, keyakinan pada kemampuan yang dimiliki, kemampuan mengelola lingkungan dan masa depan, punya rasa humor, punya banyak harapan, memiliki srategi menghadapi stress, memiliki nilai-nilai positif yang dipegang dan diyakini, memiliki perspektif yang seimbang dalam pengalaman, memiliki ketabahan, keuletan dan bersikap menyelesaikan jika ada masalah.

Pascarella dan Terenzini (1998) mengatakan bahwa konsep diri yang positif dan pandangan mental yang positif cenderung memperkaya pengalaman mahasiswa karena mereka secara intrinsik memiliki motivasi untuk memnuhi kewajiban akademik mereka. Bandura (1993) juga mengatakan bahwa self-efficacy memiliki implikasi penting bagi motivasi dimana mahasiswa menilai dirinya memiliki kemampuan dan usaha untuk mencapai keberhasilan akademiknya. Adapun internal locus of control adalah keyakinan individu tentang hasil yang dapat dicapai dalam hidup ini berdasarkan usaha yang dikerjakan serta kemampuan yang dimiliki (Clauss-Ehlers, Yang, \& Chen, 2006). Tokoh lainnya yaitu Fitch dan Marshall (2003) juga mengatakan bahwa individu yang berhasil akan optimis terhadap masa depannya sehingga mereka dapat mengendalikan apa yag ada di lingkungannya. Sejumlah faktor pendukung dari personal individu diperoleh dari pengalaman dan situasi yang berbeda dalam kehidupan mahasiswa.

Faktor pendukung berikutnya berasal dari keluarga dimana keluarga dapat memberikan pengaruh positif maupun pengaruh negatif bagi keberhasilan akademik mahasiswa. Sacker dan Schoon (2007) mengatakan bahwa mahasiswa yang berhasil tergantung pada dukungan yang diberikan oleh keluarga dan peran orang tua sebagai pengasuh dan motivator. Mahasiswa mendapatkan keuntungan dari keterlibatan orang tua melalui kehadiran yang baik, tingkat penyelesaian pekerjaan rumah yang baik, tingkat kelulusan yang baik, keterlibatan dalam kegiatan ekstrakurikuler, dan orang tuan yang memiliki sikap positif. Keluarga adalah lingkaran masyarakat terkecil yang dapat menyediakan kesempatan untuk mengembangkan kemampuan belajar yang dimiliki siswa. Keluarga terus mencari dukungan pengembangan kesehatan, fisik dan intelektual. Peran keluarga sangat penting dalam mendukung pencapaian akademik siswa terutama dalam menghadapi sejumlah kendala atau masalah yang tidak dapat diselesaikan (Werner dan Smith, 2001). Keterlibatan keluarga terutama orang tua sangat penting dalam keberhasilan akademik siswa (Bernard 1991). Faktor pendukung dari keluarga memiliki komitmen yang sangat mendasar dalam menyelesaikan program sarjana di perguruan tinggi yang meliputi 
dukungan moral, keuangan, dukungan sehari-hari, mempertahankan minat, pujian dan sebagainya. Dukungan dari orang tua adalah faktor kunci yang mempengaruhi aspirasi mahasiswa untuk masuk ke perguruan tinggi bagaimanapun tingkat pendidikan orang tua, dan sebaliknya kurangnya dukungan keluarga menjadi penghalang keberhasilan mahasiswa di perguruan tinggi.

Faktor pendukung berikutnya berasal dari Institusi pendidikan dimana mahasiswa menghabiskan waktu mereka Institusi harus bertindak sebagai perekat yang menyatukan semua faktor pendukung agar menguntungkan mahasiswa. Institusi menjadi tempat mereka berkembang, belajar melalui keterlibatan sosial dan akademik. Namun Braxton, Bray dan Berger (2000) mengatakan bahwa lingkungan perguruan tinggi menghadapi banyak tantangan dalam upaya memberikan iklim yang mendukung pembentukan resiliensi akademik mahasiswa. Iklim kampus seharusnya menyambut hangat semua mahasiswa, memberikan kenyamanan dan berkontribusi tehadap keberhasilan mahasiswa.

Pengalaman positif seperti interaksi positif dengan teman sebaya, interaksi positif dengan mahasiswa satu fakultas, regulasi dan peraturan yang jelas, harapan pencapaian yang tinggi, umpan balik yang membangun, dan keterlibatan akademik untuk mendukung perilaku resiliensi (Niesel \& Griebel, 2005). Pengaruh teman sebaya yang baik juga penting ketika mengambil keputusan pemilihan karir dan dosen juga menjadi aset bernilai bagi mahasiswa. Interaksi yang bermakna antara mahasiswa dan dosen memberikan keuntungan sosial dan akademik bagi mahasiswa (Werner \& Smith, 1992).

Menurut Reed, McMillan dan McBee (1995) program intervensi seperti konseling dan penasehat dalam institusi merupakan sumber yang bernilai untuk membantu mahaisswa mendapat bantuan agar bisa betahan dalam situasi yang sulit. Institusi akademik membantu mahasiswa mengembangkan resiliensi akademik dengan menyediakan lingkungan belajar yang positif dan aman, menciptakan harapan akademik yang tinggi namun dapat tercapai serta memfasilitasi keberhasilan akademik dan sosial mahasiswa.

Adapun faktor pendukung yang berasal dari lingkungan sosial meliputi teman sebaya yang mendukung, pengaruh komunitas yang positif seperti komunitas ibadah, teman di luar kampus yang yang mudah dihubungi, komunitas olahraga, serta role model yang positif. Faktor pendukung lingkungan meliputi juga komunitas tetangga, role model, mentor, pelatih, tetangga, dan konselor (Garmezy, 1991). Teman sebaya yang memiliki pola pikir yang sama, tujuan serta latar belakang yang sama menjadi pengaruh penting bagi pencapaian akademik mahasiswa karena mereka akan melihat bahwa mereka tidak sendiri dalam berjuang (Giordano, 1993). Mahasiswa yang berhasil biasanya memiliki role model dan pihak yang peduli pada mereka yang selalu memberikan masukan dan bantuan dalam mengambil keputusan yang baik. Mereka juga memiliki kemampuan untuk memiliki teman yang baik sehingga pengaruh teman sebaya itu penting ketika membuat keputusan untuk tetap berjuang di perguruan tinggi. Benard (1995) mengatakan bahwa hubungan dengan teman sebaya memberikan kontribusi terhadap perkembangan sosial, kognitif, dan kemampuan sosialisasi mahasiswa.

Faktor yang mempengaruhi perkembangan resiliensi akademik mahasiswa juga berhubungan dengan orang dewasa sekitar yang ikut memberikan dukungan dan kontribusi. 
Menurut Werner (1993), mahasiswa yang berhasil memiliki keyakinan keyakinan pada diri mereka sendiri bahwa ada makna hidup setelah kesulitan dan kesusahan. Komunitas ibadah memberikan stabilitas dan struktur resiliensi pada mahasiswa. Interaksi yang terjadi antara faktor pendukung yang berasal dari individu mahasiswa, faktor pendukung dari keluarga, faktor pendukung dari institusi pendidikan, serta faktor pendukung dari lingkungan sosial menghasilkan resiliensi akademik (Pianta \& Walsh, 1998). Penelitian Morales (2010) melihat individu yang memiliki resiliensi akademik memiliki hubungan yang positif dengan teman sebaya, mendapat dukungan dari keluarga, dan dukungan dari masyarakat.

Menurut Kendra (2003) penelitian tentang resiliensi akademik menyarankan sejumlah hal untuk pembentukan resiliensi seperti membangun hubungan dengan orang lain, menguatkan ketrampilan adaptif dan regulasi diri, serta menerapkan sistem keyakinan dan tradisi yang ada dalam budaya dan agama. Salah satu tradisi yang disarankan dalam agama adalah bersyukur atas apa yang dimiliki dan dihadapi. Individu dibekali kemampuan menghadapi kondisi stress dengan bersyukur karena bersyukur dapat meningkatkan kepuasan hidup, menurunkan keinginan terhadap materi, serta menjadi penguat dalam hubungan sosial (Emmons \& McCullough, 2003).

Bersyukur digambarkan oleh Lambert, Graham dan Fincham (2009) sebagai faktor yang dapat mengendalikan efek depresi terutama membantu menghargai kembali situasi yang penuh dengan masalah menjadi terasa lebih ringan. Cannon (2002) juga menunjukkan bahwa syukur adalah salah satu pembeda antara mereka yang dapat bertahan dan syukur itu ada pada cerita para korban yang bisa bertahan. Ryan (2006) menambahkan bahwa syukur merupakan kekuatan yang luar biasa untuk menaikkan kembali individu yang jatuh dan membuat individu dapat kembali fokus pada apa yang dinikmati dalam hidup meskipun mereka berada pada kondisi yang paling sulit.

Konsep bersyukur ada di semua budaya, ras, dan lintas wilayah dan menganggap hal itu adalah kepribadian yang positif meskipun bentuknya berbeda-beda cara pengungkapan rasa syukur tersebut. Peterson dan Seligman (2005) mengartikan syukur sebagai rasa berterimakasih dan sukacita karena mendapatkan hadiah, apakah hadiah itu menjadi manfaat nyata dari yang lain atau momen kebahagiaan karena keindahan alam. McCullough, Kilpatrick, Emmons, dan Larson (2001) mengartikan syukur sebagai pengaruh moral karena syukur itu mendorong perilaku moral, dan perilaku yang dihasilkan dari kepedulian terhadap orang lain.

McCullough, Emmons, dan Tsang (2002) menambahkan bahwa sifat bersyukur memiliki empat aspek yaitu intensitas, frekuensi, rentang waktu, dan kepadatan. Rentang waktu diartikan sebagai jumlah keadaan hidup yang perlu disyukuri sedangkan kepadatan diartikan dengan jumlah orang yang harus diucapkan terima kasih atas setiap hasil positif yang didapatkan. Kondisi orang yang bersyukur lebih banyak berterima kasih setiap harinya, merasa berterima kasih atas semua aspek kehidupan yang ada dalam hidupnya seperti keluarga, agama, pekerjaan dan lingkungan yang dimiliki. Syukur adalah kebajikan dan watak manusia, maka individu yang bersyukur selalu merasa berterima kasih dalam segala bentuk kondisi dan waktu (Emmons \& Crumpler, 2000).

Menurut Emmons dan Shelton (2002) bersyukur mengacu pada kebiasaan baik dari karakter personal individu dan itu diajarkan dalam agama yang ada di dunia. Rind dan Bordia 
(1995) mengatakan bahwa bersyukur berfungsi untuk meningkatkan hidup individu melalui perasaan berharga dan memiliki manfaat bagi sosial. Sedangkan menurut Watkins (2004), bersyukur dan bahagia ada dalam satu tingkatan dimana individu yang merespon situasi dengan syukur akan lebih bahagia karena merasa memiliki manfaat dalam hidupnya. Emmons (2007) menjelaskan bahwa ada beberapa hal yang dapat menjadi intervensi melatih bersyukur yaitu menuliskan sejumlah hal yang patut disyukuri dalam hidup ini, menuliskan 3-5 hal setiap hari apayang disyukuri dan alasannya, menuliskan kartu atau surat terima kasih yang sudah membantu dalam hidup, mengingat hal yang buruk yang pernah kita alami, serta coba tanyakan apa yang saya terima dari ..., apa yang saya sudah berikan pada ..., dan masalah apa yang sudah saya buat. Tokoh lainnya juga menyarankan sejumlah upaya untuk melatih bersyukur yaitu Froh (2008) yang menganjurkan untuk beribadah sebagai upaya mengungkapkan syukur, dan menghitung nikmat yang telah diterima.

Peterson dan Seligman (2004) mengartikan bersyukur dalam arti yang lebih sempit yaitu respon terima kasih setelah menerima sesuatu yang bernilai baik berbentuk materi maupun momen karena keindahan alam. Emmons dan McCullough (2003) mengartikan bersyukur sebagai konsep emosi, sikap, pandangan moral, kebiasaan, kepribadian, dan respon menghadapi sitausi. Froh, Kashdan (2009) mengatakan bahwa bersyukur dialami oleh individu ketika menerima sesuatu yang berharga sehingga sebagai bentuk penghargaan ketika seseorang melakukan sesuatu yang baik dan bermanfaat. Bersyukur adalah ekspresi penghargaan terhadap kontribusi yang diterima dari individu lain. Wood, Maltby, Stewart, Linley, \& Joseph (2008) menjelaskan delapan domain bersyukur yaitu ekpsresi penghargaan terhadap perilaku kebaikan yang diterima dari orang lain, fokus pada apa yang dimiliki daripada apa yang tidak dimiliki, perasaan kagum saat melihat keindahan, membagikan kebaikan kepada orang lain setelah menerima, fokus pada hal positif saat ini, penghargaan terhadap pemahaman bahwa hidup ini singkat, perbandingan sosial yang positif antara diri sendiri dan orang lain, dan perbedaan individu dalam mengalami efek bersyukur.

Emmons (2003) memberikan konsep yang lebih luas tentang syukur yaitu emosi, sikap, pandangan moral, kebiasaan, trait kepribadian, atau respon coping. Syukur adalah ungkapan berterima kasih dalam hidup pada orang lain, situasi, dan keadaan dalam hidup, pada apa yang kita terima, kita alami dan apa yang dipelajari. Syukur juga menjadi sumber spiritual yang dimiliki, ungkapan terima kasih atas kelebihan yang dimiliki, atas apa yang kita terima dan yang kita berikan, kualitas dalam diri yang kita miliki, serta kemakmuran dan keberkahan yang diterima. Wood, Froh, dan Geraghty (2010) menemukan sejumlah faktor yang dapat menimbulkan bersyukur yaitu penghargaan terhadap kehidupan seseorang, penghargaan terhadap keindahan alam dan dunia, fokus pada manfaat personal dan lingkugan yang positif, dan aspek hubungan interpersonal.

Penelitian Watkins (2004) menemukan bahwa syukur merupakan salah satu karakteristik dengan rasa memiliki tujuan seperti integritas dan optimis. Rasa memiliki tujuan adalah salah satu faktor pendukung dari resiliensi sehingga dapat dikatakan bahwa syukur berhubungan dengan resiliensi. Singkatnya dapat dikatakan bahwa syukur dapat membantu individu untuk menghadapi kesulitan dan itu adalah kemampuan resiliensi. 
Cannon (2002) dalam penelitiannya menemukan bahwa syukur berhubungan dengan resiliensi. Namun penelitian Fredrickson (2003) mengatakan sebaliknya dimana syukur tidak berhubungan dengan resiliensi. Banyak penelitian yang mengatakan bahwa orang yang bersyukur tidak mudah merusak dirinya, lebih pro sosial, dan bersikap lebih bermoral. Wood, Maltby, Gillett, Linley, dan Joseph (2008) meneliti hubungan antara bersyukur, dukungan sosial, stress dan depresi pada mahasiswa baru. Hasilnya menunjukkan bahwa bersyukur yang tinggi membuat individu mendapatkan dukungan sosial yang tinggi serta memiliki tingkat stress dan depersi yang rendah. Nelson (2009) menegaskan bahwa semua agama di dunia menyakini bahwa bersyukur adalah prinsip yang penting dan umum. Ungkapan rasa syukur adalah bentuk ibadah yang paling tinggi dan dan universal sifatnya sehingga tidak ada agama di dunia ini yang tidak menganggap bersyukur itu penting (Emmons dan Crumpler, 2000)

Emmons (2007) menjelaskan bahwa bersyukur secara positif berhubungan dengan hal kritis yaitu kepuasaan hidup, kesehatan, kebahagiaan, self-esteem, optimisme, harapan, empati, dan keinginan untuk memberikan dukungan kepada orang lain. Sebaliknya tidak bersyukur berhubungan dengan kecemasan, depresi, iri hati, dn kesepian. Hubungan yang positif antara bersyukur dengan atribut sosial lainnya juga dibahas oleh McCullough, Emmons Kilpatrick dan Larson (2001) dimana dikatakan bahwa bersyukur berpengaruh pada perilaku moral. Tiga pengaruh bersyukur dalam perilaku moral adalah sebagai respon terhadap persepsi perilaku moral yang ditunjukkan orang lain, motivator untuk bersikap secara bermoral kepada orang lain, serta mendorong individu untuk bersikap bermoral.

Selanjutnya Lyubomirsky (2005) menambahkan pentingnya bersyukur sebagai antidote emosi negatif, menetralisir iri hari, kerendahan hati dan kekhawatiran. Perkembangan syukur tampaknya merupakan sebuah proses. Sejumlah penelitian menemukan bahwa syukur berguna bagi kesejahteraan individu dan masyarakat. Syukur dapat memberikan pengaruh positif terhadap kepuasan hidup, sikap optimis, harapan, kebahagiaan, dan kesehatan. Di sisi lain syukur berhubungan negatif dengan perasaan iri, dan depresi (Emmons and McCullough, 2003). Orang yang punya rasa syukur cenderung memiliki karakteristik prososial kepada orang lain dengan konsisten sehingga syukur dapat berguna bagi masyarakat. Selanjutnya McCullough, Emmons, dan Tsang (2002) mengatakan bahwa syukur berhubungan secara positif dengan spiritualitas dan keagamaan dan berhubungan negatif dengan sikap materialistis. Penelitian Polak dan McCullough (2006) menggambarkan bahwa profil hedoisme berlawanan dengan orang yang bersyukur dan sikap bersyukur dapat menurunkan pengaruh negatif dari mengejar materialis seperti tidak bahagia, dan tidak puas dengan kehidupan. Syukur dapat lebih kompleks sifatnya seperti yang disampaikan oleh Naito, Wangwan, dan Tani (2005) yang meneliti tentang rasa bersyukur mahasiswa di Jepang dan Thailand. Mereka menemukan bahwa mahasiswa pada kedua negara tersebut memiliki perasaan positif seperti bahagia, hangat dan berterima kasih serta perasaan negatif (malu, menyesal menyebabkan masalah,kegelisahan dan merasa berhutang setelah menerima bantuan). Hasil penelitian itu menjelaskan bahwa perasaan positif dan perasaan merasa berhutang adalah komponen bersyukur. Perasaan positif diasosiasikan dengan ekspresi wajah dan verbal, memberikan kembali baik bentuknya uang atau barang, serta meningkatkan perilaku prososial. 
Namun penelitian Sheldon dan Lyubomirsky (2005) menemukan bahwa rasa beryukur tidak menurunkan pengaruh negatif dan tidak menaikkan pengaruh positif di antara mahassiwa. Watkins (2004) mengatakan bahwa syukur berhubungan secara positif dengan hal-hal yang disengaja (seperti ingatan dari kejadian khusus baik positif maupun negatif) dan hal yang sifatnya intrusif (mengganggu) seperti mengingat peristiwa yang berlawanan. Ini artinya bahwa kejadian hidup yang menyenangkan datang kepada siswa yang banyak bersyukur daripada mereka yang kurang bersyukur (Watkins, 2004)

Sejumlah penelitian menunjukkan bahwa bersyukur dinilai efektif sebagai kemampuan untuk menghadapi depresi. Bersyukur secara langung mendorong dukungan sosial dan menjadi protective agent yang mengurangi stress dan depresi. (Wood, Joseph, \& Linley, 2007). Bersyukur juga mendorong dukungan sosial menjadi lebih tinggi tingkatannya serta menurunkan stress dan depresi. Bersyukur juga berhubungan positif dengan upaya mencari dukungan sosial baik yang bentuknya emosi maupun yang berbentuk instrumen, perkembangan yang positif, rencana dan upaya menghadapi masalah dengan cara positif. Sebaliknya bersyukur berhubungan negatif dengan penyimpangan perilaku, menyalahkan diri sendiri, dan penolakan.

Syukur berhubungan dengan stress, dimana syukur dapat menfasilitasi kekuatan yang menekan munculnya stress (Wood, Joseph, \& Linley, 2007). Sejumlah penelitian menunjukkan bahwa syukur berhubungan dengan tingkat stress yang rendah (Krause, 2006). Penelitian Wood, Maltby, Stewart, Linley, \& Joseph (2008) pada mahasiswa baru di semester awal menunjukkan tingkatan stress yang rendah hal itu dikarenakan mahasiswa yang memiliki sikap bersyukur cenderung aktif mekasime coping stressnya seperti memiliki ketrampilan memecahkan masalah dan proses emosi. Sejumlah penelitian berspekulasi bahwa syukur memiliki peran penting dalam menurunkan stress dan secara signifikan menjadi isu dalam kesehatan.

Emmons (2003) menjelaskan mengapa bersyukur dapat meningkatkan well-being karena bersyukur memfasilitasi kemampuan menghadapi stress, mengurangi emosi yang negatif dari hasil perbandingan terhadap diri dan sosial, mengurangi upaya mengejar materi, meningkatkan self-esteem, membangun sumber sosial, meningkatkan akses keingatan positif. Selain itu Fredrickson (2001) menambahkan bahwa bersyukur memotivasi perilaku moral dan pikiran yang spiritual. Wood, Maltby, Gillett, Linley, dan Joseph (2008) meneliti hubungan antara bersyukur, dukungan sosial, stress dan depresi pada mahasiswa baru. Hasilnya menunjukkan bahwa bersyukur yang tinggi membuat individu mendapatkan dukungan sosial yang tinggi serta memiliki tingkat stress dan depersi yang rendah.

Kehidupan di perguruan tinggi dapat menjadi transisi hidup yang signifikan pada mahasiwa yang menuntut kemampuan beradaptasi. Mahasiswa baru khususnya seringkali bukan mengalami pengalaman yang menyenangkan melainkan kesulitan dan ketakutan. Mereka beradaptasi dengan segala kehidupan kampus yang baru, berkenalan dengan orangorang baru, dan menghadapi tantangan akademik yang berat.

Menurut Seligman, Steen, Part, dan Peterson (2005) resiliensi akademik adalah topik khusus dan menarik untuk melihat pencapaian akademik siswa dan menganalisa proses kognitif dan afektif pada siswa. Pemahaman terhadap bagaimana resiliensi mahasiswa dalam 
menghadapi segala bentuk kesulitan yang ada dalam dunia akademik menjadi hal penting untuk diteliti. Resiliensi pada pendidikan tinggi juga mulai banyak mendapatkan perhatian dalam penelitian karena itu diangap sebagai upaya mahasiswa bertahan dalam kondisi sulit perguruan tinggi (Boyer, 2005). Meskipun syukur menjadi salah satu intervensi psikologi positif yang berhasil membantu resiliensi namun intervensi itu belum menjalani pengujian yang ketat.

Kajian resiliensi banyak ditemukan berhubungan dengan variabel psikologi lainnya. Penelitian Javanmard (2013) menunjukkan bahwa keyakinan regilius berhubungan secara positif dengan resiliensi. Keyakinan yang kuat secara religious menjadi prediktor terbentuknya variabel resiliensi. Canon (2002) mengatakan bahwa syukur berhubungan dengan resiliensi, namun penelitian Fredrickson, Tugade, Waugh, dan Larkin (2003) menunjukkan hasil sebaliknya dimana syukur tidak berhubungan dengan resiliensi. Sejumlah karakter juga dianggap sebagai faktor pendukung resiliensi seperti keberanian, kreatifitas, keingintahuan, keadilan, memaafkan dan pengampunan, harapan, humor, integritas, kebaikan, kepemimpinan, suka belajar, berpikiran terbuka terhadap masukan, ketahanan diri, perspektif, kebijaksanaan, regulasi diri, kecerdasan sosial, spiritualitas, dan daya hidup. Namun masih sedikit sekali kajian yang membahas hubungan resiliensi akademik dengan rasa bersyukur. Selain itu hasil penelitian yang melihat hubungan antara resiliensi dengan rasa bersyukur terlihat tidak konsisten.

Atas dasar alasan-alasan tersebut, penelitian ini bertujuan untuk melihat hubungan bersyukur dengan tingkat resiliensi mahasiswa baru di UIN bandung. Tingkat resiliensi mahasiswa perlu untuk mendapatkan perhatian karena semakin tinggi tingkat resiliensi yang dimiliki mahasiswa akan semakin baik penyesuaian dirinya secara psikologis.

\section{METODE PENELITIAN}

Penelitian ini merupakan penelitian kuantitatif dengan menggunakan desain non eksperimen. Penelitian ini menggunakan satu variabel bebas yaitu bersyukur dan satu variabel terikat yaitu resiliensi. Populasi dalam penelitian ini adalah mahasiswa UIN Sunan Gunung Djati Bandung yang terdaftar pada tahun ajaran 2017/2018. Ada 400 mahasiswa dilibatkan dalam penelitian ini untuk mendapatkan data bersyukur dan resiliensi. Sample dianggap sama karena memiliki karakteritik yang sama yaitu ada di tahun pertama tahap perguruan tinggi dan masih dalam masa adaptasi dengan dunia akademik di perguruan tinggi. Teknik sampling yang digunakan adalah clucter random Sampling. Instrumen pengukuran yang digunakan dalam penelitian ini adalah skala bersyukur dan skala resiliensi. Peneliti mengadaptasi skala alat ukur ConnorDavidson Resilience Scale (CD-RISC) yang dikembangkan oleh Connor dan Davidson (2003) yang terdiri dari 25 aitem. Setiap aitem memiliki nilai menggunakan skala likert (04), dimana semakin tinggi nilai yang diperoleh maka menunjukkan semakin tinggi tingkat resiliensinya. Sedangkan bersyukur menggunakan The Gratitude Questionnaire-6 yang dikembangkan oleh McCullough, Emmons, \& Tsang (2002). Ada 7 pilihan jawaban dengan skala likert yaitu mulai dari 1 (sangat tidak setuju) sampai nilai 7 (sangat setuju). Teknik analisis data yang digunakan untuk uji hipotesis dalam penelitian ini adalah uji regresi linier sederhana. 


\section{HASIL PENELITIAN DAN PEMBAHASAN}

Sebagaimana yang telah diajukan dalam bab 1 bahwa hipotesis dalam penelitian ini adalah ada pengaruh rasa bersyukur terhadap resiliensi mahasiswa UIN Sunan Gunung Djati Bandung. Pengujian hipotesis dilakukan dengan menganalisis bersyukur sebagai variabel bebas dan resiliensi sebagai variabel terikat. Analisis regresi sederhana dilakukan untuk melihat pengaruh bersyukur terhadap resiliensi dan hipotesis terjawab dari hasil analisis yang disajikan pada tabel 1 berikut ini.

Tabel 1. Hasil analisis model 1

\begin{tabular}{|c|c|c|c|c|}
\hline \multicolumn{5}{|c|}{ Coefficients $^{\mathrm{a}}$} \\
\hline \multirow[b]{2}{*}{ Model } & \multicolumn{3}{|c|}{ Unstandardized Coefficients Standardized Coefficients } & \multirow[b]{2}{*}{ Sig. } \\
\hline & $\overline{\mathrm{B}}$ & Std. Error & Beta & \\
\hline 1 (Constant) & 82.278 & .405 & & 203.071 .000 \\
\hline bersyukur & -10.992 & .571 & .821 & $19.237 \quad .000$ \\
\hline a. Dependen & it Variable & esiliensi & & \\
\hline
\end{tabular}

Hasil pada tabel 1 di atas menunjukkan variabel bersyukur memiliki nilai $t=19,237$ dengan probabilitas $0,000<0,05$ sehingga H0 ditolak. Dengan demikian dapat dikatakan bahwa terdapat pengaruh signifikan rasa bersyukur terhadap resiliensi. Nilai koefisien sebesar 19,237 menunjukkan nilai positif yang artinya semakin tinggi rasa bersyukur yang ada pada mahasiswa maka semakin tinggi resiliensi yang dimiliki.

Berikutnya tabel 2. menunjukkan besarnya pengaruh variabel bebas terhadap variabel terikat.

Tabel 4.2. Hasil analisis model 1

Model Summary

\begin{tabular}{lllll}
\hline Model & $\mathrm{R}$ & $\mathrm{R}$ Square & Adjusted R Square & Std. Error of the Estimate \\
\hline 1 & $.826^{\mathrm{a}}$ & .682 & .678 & 3.80087
\end{tabular}

a. Predictors: (Constant), bersyukur

b. Dependent Variable : resiliensi

Seperti terlihat pada tabel 2 nilai $\mathrm{R}$ Square sebesar 0,682 yang artinya pengaruh rasa bersyukur terhadap resiliensi pada mahasiswa UIN Sunan Gunung Djati Bandung adalah sebesar 68,2\%. Dengan kata lain ada sekitar 31,8\% resiliensi dipengaruhi oleh faktor lainnya. Berdasarkan analisis yang telah dilakukan, maka hasil penelitian ini menunjukkan bahwa ada pengaruh rasa bersyukur terhadap resiliensi mahasiswa UIN Sunan Gunung Djati Bandung. Adapun besarnya kontribusi rasa bersyukur terhadap resiliensi adalah sebesar $68,2 \%$.

Hasil uji hipotesis menunjukkan ada pengaruh signifikan variabel bersyukur terhadap variabel resiliensi. Hasil tersebut mendukung hipotesis yang diajukan dalam penelitian ini. Temuan penelitian ini menunjukkan bahwa rasa bersyukur memberikan kontribusi terhadap terbentuknya resiliensi pada mahasiswa. Hasil penelitian ini sama dengan 
penelitian Cannon (2002) yang juga menemukan bahwa syukur berhubungan dengan resiliensi.

Rasa syukur terlihat memberikan kontribusi yang cukup besar terhadap terbentuknya resiliensi mahasiswa. Interpretasi yang dapat diberikan pada hasil penelitian ini adalah bahwa rasa bersyukur yang tinggi membuat mahasiswa memiliki tingkat stress dan depresi yang rendah sehingga membentuk resiliensi pada mahasiswa. Hal itu digambarkan oleh Wood, Maltby, Gillett, Linley, dan Joseph (2008) bahwa ada hubungan antara bersyukur, dukungan sosial, stress dan depresi pada mahasiswa baru dimana bersyukur yang tinggi membuat individu mendapatkan dukungan sosial yang tinggi dan akhirnya mereka memiliki tingkat stress dan depersi yang rendah.

Adanya kontribusi bersyukur terhadap terbentuknya resiliensi menunjukkan bahwa bersyukur membuat mahasiswa memiliki kontrol diri yang lebih baik. Salah satu faktor protektif yang membentuk resiliensi adalah locus of control (Banerjee dan Pyles, 2004). Ketika mahasiswa mampu mengontrol dirinya maka upaya menghadapi dan memecahkan masalah menjadi hal yang tidak terlalu menguras energi. Mereka menjadi yakin bahwa dengan bersyukur dapat melihat apa yang telah dimiliki dan apa yang menjadi kelebihan pada dirinya. Rasa dan sikap bersyukur yang dimiliki mampu mengarahkan mahasiswa bertahan dalam menghadapi situasi yang sulit. Fokus bersyukur yang tidak hanya melihat pada kekurangan tapi lebih melihat pada apa yang telah dimiliki oleh individu membuat mahasiswa memiliki banyak laternatif pemecahan masalah yang itu menjadi pembentuk resiliensi.

Kondisi bersyukur juga akan menghasilkan energi positif sehingga membuat individu lain merasa nyaman berada bersama mereka. Hal itu digambarkan oleh Wood, Maltby, Gillett, Linley, dan Joseph (2008) bahwa individu yang bersyukur akan mendapatkan dukungan sosial yang tinggi dan itu akan membuat mereka memiliki tingkat stress dan depresi yang rendah. Individu mahasiswa yang memiliki sikap bersyukur akan cenderung melakukan kegiatan yang positif dan mengarahkan mereka pada sosialisasi dengan individu lain. Hubungan yang dijalin dengan mahasiswa dan dosen di universitas akan membuat mereka mendapatkan dukungan sosial yang membantu meringankan stress yang dirasakan. Connor dan Davidson (2003) menggambarkan sosialisasi yang dilakukan mahasiswa itu membuat mereka mampu menghadapi kesulitan yang dihadapi dan belajar beradaptasi secara positif dengan kejadian-kejadian yang negatif.

Sejumlah faktor protektif juga terlihat pada individu mahasiswa yang ada di UIN Sunan Gunung Djati Bandung. Berbagai aktivitas yang ada di kampus membuat mahasiswa terlibat dan mendapatkan dukungan sosial baik dari institusi universitas maupun dari teman sebaya. Mahasiswa menunjukkan sikap bersyukurnya dengan menikmati pertemanan yang ada di lingkungan kampus. Peran teman sebaya menjadi salah satu faktor protektif yang dapat membentuk resiliensi mahasiswa selama beradapatasi dengan kondisi perkuliahan.

Lingkungan sosial seperti teman sebaya dan komunitas yang positif baik komunitas ibadah, teman di luar kampus yang yang mudah dihubungi, komunitas olahraga, ataupun role model yang positif membuat mahasiswa mampu beradaptasi dengan komunitas yang diikuti. Emmons (2007) menjelaskan bahwa bersyukur membuat individu menjadi lebih prososial serta memiliki sikap peduli. Hubungan positif yang dijalin dengan teman sebaya menurut 
adalah salah satu pembentuk resiliensi akademik karena individu yang memiliki hubungan positif dengan teman sebaya akan menjadi kuat menghadapi berbagai bentuk kesulitan yang ada karena mendapatkan dukungan (Morales, 2010).

Berikutnya adalah hubungan yang positif antara bersyukur dengan atribut sosial lainnya juga dibahas oleh McCullough, Emmons Kilpatrick dan Larson (2001) dimana dikatakan bahwa bersyukur berpengaruh pada perilaku moral. Adanya rasa bersyukur yang dimiliki mahasiswa mendorong individu untuk bersikap bermoral. Lingkungan kampus memberikan peluang bagi mahasiswa untuk melakukan kegiatan spiritual seperti sholat berjamaah, ada asrama dengan segala kegiatan religius. Keterlibatan mahasiswa dalam sejumlah kegiatan keagamaan dan sosial mengarahkan mereka untuk memiliki pandangan positif serta self-esteem yang tinggi yang itu merupakan faktor pembentuk resiliensi akademik mahasiswa Bormab dan Overman (2004) juga mengatakan bahwa dukungan lingkungan kampus berhubungan dengan resiliensi siswa.

Rasa syukur mempengaruhi tingkat resiliensi dengan terbentuknya sikap prososial yang dimiliki mahasiswa. Rancangan kegiatan dalam pembelajaranan maupun program universitas seperti kuliah kerja nyata membentuk sikap prososial pada mahasiswa. Orang yang punya rasa syukur cenderung memiliki karakteristik prososial kepada orang lain dengan konsisten sehingga syukur dapat berguna bagi masyarakat.

Bersyukur dapat mempengaruhi tingkat resiliensi mahasiswa karena rasa dan sikap bersyukur yang dimiliki akan membuat mereka mampu meminimallisir emosi negatif yang muncul. Ketika mahasiswa melihat ada individu lain yang memliki kelebihan dari dirinya maka mereka akan mengatakan bahwa saya pun punya kelebihan yang diberikan Tuhan. Hal itu juga digambarkan oleh Lyubomirsky (2005) bahwa bersyukur dapat berperan sebagai antidote emosi negatif, menetralisir iri hari, kerendahan hati dan kekhawatiran. Berbagai kondisi yang membuat mahasiswa melihat apa yang tidak dimiliki menjadi hal yang positif karena dimensi bersyukur adalah fokus pada apa yang telah dimiliki bukan pada apa yang belum ada pada dirinya. Connor dan Davidson (2003) mengilustrasikan kondisi tersebut sebagai kondisi resiliensi dimana individu mahasiswa mampu menghadapi kondisi yang tidak nyaman, sabar, dan memiliki toleransi adaptif terhadap apa yang dihadapi.

Emmons (2007) menjelaskan bahwa bersyukur secara positif berhubungan dengan kepuasaan hidup dan mereka yang memiliki resiliensi tinggi adalah mereka yang memiliki persepsi tinggi terhadap kepuasan hidup. Dengan kata lain individu yang bersyukur memiliki kepuasan terhadap apa yang dimiliki dalam hidupnya dan itu merupakan pembentuk resiliensi akademik pada mahasiswa. Pengaruh bersyukur terhadap resiliensi mahasiswa UIN Bandung terlihat dari cara mereka bersyukur atas apa yang dimiliki. Konsep bersyukur dalam agama Islam juga menjadi bahan pembentuk resiliensi mahasiswa karena secara tidak langsung proses pembelajaran dalam perkuliahan memasukan unsur bersyukur.

Emmons and McCullough (2003) juga mengatakan bahwa syukur dapat memberikan pengaruh positif terbentuknya sikap optimis, harapan, kebahagiaan, dan kesehatan. Di sisi lain syukur berhubungan negatif dengan perasaan iri, dan depresi. Tampilan sikap bersyukur mahasiswa UIN Bandung dapat dilihat dari sikap yang ditunjukkan dan itu menjadi sumber pembentuk resiliensi mereka. Masten (2009) mengatakan bahwa kemampuan untuk dapat 
beradaptasi dengan perubahan dan menghadapi kondisi sulit adalah pengertian umum dari resiliensi.

Gambaran lain yang mencoba menjelaskan variabel bersyukur dapat membentuk resiliensi pada mahasiswaUIN bandung adalah sejumlah aktivitas mahasiswa UIN Bandung yang bersifat keagamaan seperti sholat berjamaah, mata kuliah yang bermuatan agama serta iklim akademik yang religious. Banerjee dan Pyles (2004) menjelaskan bahwa salah satu faktor protektif yang membuat terbentuknya resiliensi adalah keyakinan spiritual melalui keimanan yang dimiliki. Fredrickson (2001) juga menambahkan bahwa bersyukur memotivasi perilaku moral dan pikiran yang spiritual. Berbagai hal tersebut menjadi faktor protektif bagi terbentuknya resiliensi seperti yag disampaikan oleh McCullough, Emmons, dan Tsang (2002) bahwa syukur berhubungan secara positif dengan spiritualitas dan keagamaan.

Adapun faktor pendukung terakhir adalah lingkungan sosial seperti teman, masyarakat, dan kelompok ibadah. Sejumlah faktor pendukung tersebut mendukung keterlibatan sosial dan keterlibatan akademik yang saling berhubungan dan dianggap sebagai sistem pendukung dan kunci untuk menciptakan lingkungan yang mendukung dan mengembangkan akademik resiliensi. Werner dan Smith (2001) mengidentifikasi keyakinan dan harapan sebagai komponen inti pada resiliensi. McMillan dan Reed (1994) mengidentifikasi sejumlah upaya yang dilalui mahasiswa yang terukur memiliki resiliensi akademik yang tinggi yaitu adanya keterlibatan dalam program intervensi, sibuk dengan berbagai kegiatan untuk menggunakan waktu secara positif di perguruan tinggi. Keterlibatan akademik dan keterlibatan sosial adalah aspek penting dalam pembentukan resiliensi akademik mahasiswa.

Faktor pendukung berikutnya berasal dari Institusi pendidikan dimana mahasiswa menghabiskan waktu mereka (Braxton, Bray dan Berger, 2000). UIN Bandung sebagai institusi pendidikan Islam cukup banyak memberikan peluang bagi mahasiswa untuk belajar banyak hal tentang kehidupan. Kelas tempat perkuliahan menjadi lingkup terkecil tempat mahasiswa berinteraksi dengan individu lainnya. UIN Bandung menjadi institusi menjadi tempat mahasiswa berkembang, belajar melalui keterlibatan sosial dan akademik. Sejumlah kegiatan yang dilakukan mahasiswa di kampus membuat mereka merasa memiliki lingkungan kampus tersebut. Gonzalez dan Padilla (1997) mengatakan bahwa lingkungan akademik yang supportif dan rasa memiliki dalam institusi pendidikan menjadi prediktor yang signifikan terhadap terjadinya resiliensi.

Banyak tantangan dalam upaya memberikan iklim yang mendukung pembentukan resiliensi akademik mahasiswa dan rasa syukur yang dimiliki mahasiswa menjadi faktor protektif terbentuknya resiliensi. Pengalaman positif seperti interaksi positif dengan teman sebaya, interaksi positif dengan mahasiswa satu fakultas, regulasi dan peraturan yang jelas, harapan pencapaian yang tinggi, umpan balik yang membangun, dan keterlibatan akademik untuk mendukung perilaku resiliensi (Niesel \& Griebel, 2005).

Wood, Joseph, \& Linley (2007) juga mengatakan bahwa bersyukur mendorong dukungan sosial menjadi lebih tinggi tingkatannya serta menurunkan stress dan depresi. Bersyukur juga berhubungan positif dengan upaya mencari dukungan sosial baik yang bentuknya emosi maupun yang berbentuk instrumen, perkembangan yang positif, rencana 
dan upaya menghadapi masalah dengan cara positif. Sebaliknya bersyukur berhubungan negatif dengan penyimpangan perilaku, menyalahkan diri sendiri, dan penolakan. Hanewald's (2011) mengatakan ada 3 bentuk resiliensi yaitu (1) "overcoming the odds" yang menggambarkan kekuatan personal individu menghadapi kesulitan, (2) "coping" kemampuan menghadapi berbagai bentuk resiko negatif, dan (3) "recovery from trauma" adalah kemampuan untuk kembali bangkit dari kesulitan atau keterpurukan.

Keterkaitan syukur dengan resiliensi juga dapat dijelaskan dengan gambaran yang disampaikan oleh Wood, Joseph, dan Linley (2007) bahwa syukur berhubungan dengan stress dimana syukur dapat menfasilitasi kekuatan yang menekan munculnya stress. Ketika mahasiswa memiliki kemampuan untuk mensyukuri apa yang dimiliki dengan kondisi yang dihadapi maka itu akan membantunya bersahabat dengan stress. Sejumlah penelitian menunjukkan bahwa syukur berhubungan dengan tingkat stress yang rendah artinya ketika individu mahasiswa dapat mewujudkan rasa syukurnya dalam sikap maka mereka mampu menahan kondisi yang membuat mereka stress. Penelitian Wood, Maltby, Stewart, Linley, \& Joseph (2008) pada mahasiswa baru di semester awal menunjukkan tingkatan stress yang rendah hal itu dikarenakan mahasiswa yang memiliki sikap bersyukur cenderung aktif mekasime coping stressnya seperti memiliki ketrampilan memecahkan masalah dan proses emosi.

Smokowski (1999) juga mengatakan bahwa mahasiswa yang memiliki resiliensi akademik mampu menterjemahkan lingkungan yang sulit menjadi sumber motivasi dengan tetap mempertahankan harapan dan aspirasi yang tinggi, memiliki orientasi tujuan yang jelas, memiliki ketrampilan menyelesaikan masalah yang baik, serta memiliki kompetensi berhubungan secara sosial dengan berbagai pihak. Sejumlah penelitian berspekulasi bahwa syukur memiliki peran penting dalam menurunkan stress dan secara signifikan menjadi isu dalam kesehatan. Ketika mahasiswa memiliki rasaa syukur dan mampu bersikap positif bersyukur dalam menghadapi apapun kondisi yang ada, maka kemampuan mereka untuk menghadapi kesulitan juga semakin terasah. Tingkat resiliensi mahasiswa juga dapat dipengaruhi dari proses bersyukur yang dijalani. Connor dan Davidson (2003) menambahkan bahwa individu yang resilien tidak hanya mampu menghadapi kesulitan yang dihadapi tetapi juga dapat beradaptasi secara positif dengan kejadian-kejadian yang negatif.

Emmons (2003) menjelaskan mengapa bersyukur dapat meningkatkan well-being karena bersyukur memfasilitasi kemampuan menghadapi stress, mengurangi emosi yang negatif dari hasil perbandingan terhadap diri dan sosial. Ketika mahasiswa mampu mensyukuri apa yang dihadapi maka mereka belajar untuk beradaptasi dengan kondisi yang membuat merek atidak nyaman. Masten dkk (1990) menggambarkan karakteristik resiliensi adalah kemampuan individu menghadapi masalah, beradaptasi dengan kondisi yang tidak menyenangkan, dan menghadapi pengalaman hidup yang menekan. Pada saat mahasiswa menghadapi sejumlah tuntutan tugas dan kondisi tidak nyaman dalam berbagi kondsi maka mereka sedang dalam proses meningkatkan resiliensi. 


\section{SIMPULAN DAN SARAN}

Bersyukur terbukti memiliki kontribusi terhadap pembentukan resiliensi akademik mahasiswa UIN Sunan Gunung Djati Bandung. Pernyataan itu didukung oleh hasil penelitian ini yang menunjukkan adanya pengaruh yang signifikan dari variabel bersyukur pada variabel resiliensi. Kontribusi bersyukur cukup besar terhadap terbentuknya resiliensi mahasiswa. Fokus bersyukur yang tidak hanya melihat pada kekurangan tapi lebih melihat pada apa yang telah dimiliki oleh individu membuat mahasiswa memiliki banyak aternatif pemecahan masalah yang itu menjadi pembentuk resiliensi. Dengan kata lain rasa bersyukur yang tinggi membuat mahasiswa memiliki kemampuan bertahan dalam menghadapi situasi sulit.

Bersyukur merupakan salah satu faktor protektif personal pembentuk resiliensi akademik. Sikap bersyukur membuat mahasiswa cenderung melakukan kegiatan yang positif dan mengarahkan mereka pada sosialisasi dengan individu lain. Hubungan yang dijalin dengan mahasiswa dan dosen di universitas membuat mereka mendapatkan dukungan sosial yang membantu meringankan stress yang dirasakan. Mahasiswa menunjukkan sikap bersyukurnya dengan menikmati pertemanan yang ada di lingkungan kampus. Teman sebaya dalam komunitas positif yang bernuansa Islami juga menjadi faktor protektif yang dapat membentuk resiliensi mahasiswa selama beradapatasi dengan kondisi perkuliahan.

Rasa syukur membentuk sikap prososial pada mahasiswa yang itu merupakan sumber resiliensi akademik bagi mahasiswa. Sejumlah faktor protektif yang tersedia di UIN Sunan Gunung Djati juga ikut membantu pembentukan resiliensi mahasiswa. Aneka kegiatan positif seperti sholat berjamaah, ceramah, praktek ibadah, serta mata kuliah yang bermuatan Islam membentuk sikap prososial pada mahasiswa yang akhirnya itu berhubungan dengan resiliensi mahasiswa. Konsep bersyukur dalam agama Islam juga menjadi bahan pembentuk resiliensi mahasiswa karena mahasiswa belajar untuk menghadapi kondisi tidak nyaman, sabar, dan memiliki toleransi adaptif terhadap apa yang dihadapi. Ketika mahasiswa memiliki rasa syukur dan mampu bersikap positif dan bersyukur dalam menghadapi apapun kondisi yang ada, maka kemampuan mereka untuk menghadapi kesulitan juga semakin terasah.

Hasil penelitian ini dapat dijadikan rujukan sebagai alternatif wacana untuk merancang kegiatan positif dalam kampus UIN Sunan Gunung Djati yang membantu meningkatkan resiliensi akademik mahasiswa khususnya mahasiswa baru dalam upaya beradaptasi dengan lingkungn akademik di perguruan tinggi. Sejumlah konsep self dalam psikologi perlu mendapatkan perhatian karena berbagai kekuatan personal yang dimiliki mahasiswa dapat ditingkatkan dengan memberikan peluang dan fasilitas yang memadai.

Saran bagi penelitian berikutnya dapat menggunakan variabel lain untuk perluasan kajian tentang resiliensi. Selain itu penelitian yang sifatnya eksperimen juga dapat dilakukan dengan membuat program pengembangan potensi soft skill mahasiswa yang berangkat dari konsep psikologi positif. 


\section{Daftar Pustaka}

Alva, S. A. (1991). Academic invulnerability among Mexican-American students: The importance of protective resources and appraisals. Hispanic Journal of Behavioral Sciences, 13(1), 18-34.

Bandura, A. (1993). Perceived self-efficacy in cognitive development and functioning. Educational Psychologist, 28(2), 117-148.

Benard B (2004) Resiliency: What have we learned? San Francisco, California, USA.

Benard, B. (1995). Fostering resilience in children. ERIC Digest. ERIC Document Reproduction Service No. ED 386327

Bernard, B. (2007). The foundations of the resiliency paradigm. In N. Henderson, (Ed.) Resliency in action: Practical ideas for overcoming risks and building strengths in youth, families and communities (pp. 3-7). Ojai, CA: Resiliency in Action

Boyer, P. G. (2005). College student persistence of first-time freshmen at a midwest university: A longitudinal study. Research for Educational Reform, 10(1), 16-27.

Braxton, J. M., Bray, N. J., \& Berger, J. B., (2000). Faculty teaching skills and their influences on the college student departure process. Journal of College Student Development, 41, 215-227.

Brown, J. H., D'emidio-Caston, M., \& Benard, B. (2001). Resilience education. CA: Corwin Press, Inc

Cannon, J. T. (2002). Experiences of the 1989 Loma Prieta earthquake: A narrative analysis (Doctoral dissertation, Saybrook Graduate School, 2002). Dissertation Abstracts International, 64(4-B), 1938

Connor, K. M., Davidson, J. R. T., Lee L-C. (2003). Spirituality, Resilience, and Anger in Survivors of Violent Trauma: A Community Survey. Journal of Traumatic Stress, 16(1), 487494.

Connor, K. M., \& Davidson, J. R. T. (2003). Development of a new resilience scale: The Connor-Davidson Resilience Scale (CD-RISC). Depression and Anxiety, 18, 76-82.

Dass-Brailsford, P. D. (2005). Exploring resiliency: Academic achievement among disadvantaged black youth in South Africa. South African Journal of Psychology, 35(3), 574-591

Dyson, R., \& Renk, K. (2006). Freshmen adaptation to university life: Depressive symptoms, stress, and coping. Journal of Clinical Psychology, 62(10), 1231-1244.

Emmons, R. A., \& McCullough, M. E. (2003). Counting blessings versus burdens: an experimental investigation of gratitude and subjective well-being in daily life. Journal of Personality and Social Psychology, 84(2), 377-389

Emmons, R. A., \& Crumpler, C. A. (2000). Gratitude as a human strength: Appraising the evidence. Journal of Social and Clinical Psychology, 19(1), 56-69

Emmons, H. C. (2007). The rise and fall of resilience: Prevention and holistic treatment of depression among college students. Journal of College Student Psychotherapy, 21(3/4), 225-241.

Finn, J. D., \& Rock, D. A. (1997). Academic success among students at risk for school failure. Journal of Applied Psychology, 82(2), 221-34.

Fredrickson, B. L. (2001). The role of positive emotions in positive psychology:The broaden and build theory of positive emotions. American Psychologist, 56(3),

218-222

Fredrickson, B. L., Tugade, M. M., Waugh, C. E., \& Larkin, G. R. (2003). What good are positive emotions in crises? A prospective study of resilience and emotions following the terrorist attacks on the United States on September 11th, 2001. Journal of Personality \& Social Psychology, 84(2), 365-376. 
Froh, J. J., Sefick, W. J., \& Emmons, R. A. (2008). Counting blessings in early adolescents: an experimental study of gratitude and subjective well-being. Journal of School Psychology, 46(2), 213-33.

Froh, J. J., Kashdan, T. B., Ozimkowski, K. M., \& Miller, N. (2009). Who benefits the most from a gratitude intervention in children and adolescents? Examining positive affect as a moderator. The Journal of Positive Psychology, 4(5), 408-422.

Garmezy, N. (1991). Resiliency and vulnerability to adverse developmental outcomes associated with poverty. American Behavioral Scientist, 34(4), 416-430

Giordano, P.C., Cernkovich, S.A. \& DeMaris, A. (1993). The family and peer relations of black adolescents. Journal of Marriage and the Family, 55(2), 277-287

Gonzalez, R., \& Padilla, A. M. (1997). The academic resilience of Mexican American high school students. Hispanic Journal of Behavioral Sciences, 19(3), 301-317.

Hanewald, R. (2011). Reviewing the Literature on "At-Risk" and Resilient Children and Young People. Australian Journal of Teacher Education, 36(2), 16-27.

Javanmard. G.H. Hossein.G. (2013). Religious Beliefs and Resilience in Academic Students. Social and Behavioral Sciences. 84 (2), $744-748$

Kendra, J. and Wachtendorf, T. (2003). Elements of resilience after the world trade center disaster: Reconstituting new york city's emergency operations centre. Disasters, 27(1),37-53.

Krause, N. (2006). Gratitude Toward God, Stress, and Health in Late Life. Research on Aging, 28(2), 163-183. 70

Lyubomirsky, S., King, L., \& Diener, E. (2005). The benefits of frequent positive affect: Does happiness lead to success? Psychological Bulletin, 131(6), 803-855

Martin, A. and Marsh, H. (2006). Academic resilience and its psychological and educational correlates: A construct validity approach. Psychology in the Schools, 43(3), 267-281.

Martin, A. J., \& Marsh, H.W. (2009). Academic resilience and academic buoyancy: An encompassing multidimensional and hierarchical framing of concepts, causes, correlates, and cognate constructs. Oxford Review of Education, 35(4), 353-370.

Masten, A. S., Best, K. M., \& Garmezy, N. (1990). Resilience development: Contributions from the study of children who overcome adversity. Development and Psychopathology, 2(2), 425-444.

Masten, A. S., \& Reed, M. J. (2002). Resilience in development. In C. R. Snyder \& S. J. Lopez (Eds.), Handbook of positive psychology (pp. 74-88). New York: Oxford University Press.

Masten, A. S. (2009). "Ordinary Magic: Lessons from research on resilience in human development. Education Canada, 49 (3), 2832.

McCullough, Emmons Kilpatrick dan Larson (2001) links of grateful moods to individual differences and daily emotional experience. Journal of Personality and Social Psychology, 86(2), 295-309

McCullough, M. E., Emmons, R. A., \& Tsang, J.-A. (2002). The grateful disposition: A conceptual and empirical topography. Journal of Personality and Social Psychology, $82(1), 112-127$

McMillan, J., \& Reed, D. (1994). At-risk students and resiliency: Factors contributing to academic success. Clearing House, 67(3), 137-140.

Morales, E. E. (2010). Linking Strengths: Identifying and Exploring Protective Factor Clusters in Academically Resilient Low-Socioeconomic Urban Students of Color. Roeper Review, 32(1), 164-175

Morales, E. E., \& Trotman, F. (2004). Promoting academic success resilience in multicultural America: Factors affecting student success. New York: Peter Lang. 
Naito, T., Wangwan, J., \& Tani, M. (2005). Gratitude in university students in Japan and Thailand. Journal of Cross-Cultural Psychology, 36(2), 247-263.

Nelson, C. (2009). Appreciating gratitude: Can gratitude be used as a psychological intervention to improve individual well-being?. Counselling Psychology Review, 24(3), 38-50.

Niesel, R., \& Griebel, W. (2005). Transition Competence and Resiliency in educational institutions. International Journal of Transitions in Childhood, 1(2), 4-11.

Pancer, S. M., Hunsberger, B., Pratt, M. W., \& Alisat, S. (2000). Cognitive Complexity of Expectations and Adjustment to University in the First Year. Journal of Adolescent Research, 15(1), 38-57.

Pascarella, E. T., \& Terenzini, P. T. (1998). Studying college students in the 21 st century: Meeting new challenges. The Review of Higher Education, 21(2), 151-195.

Peterson, C., \& Seligman, M.E.P. (2004). Character strengths and virtues: A handbook and classification. New York, NY: Oxford University Press.

Pianta, R. C., \& Walsh. D. J., (1998). Applying the construct of resilience in schools: Cautions from a developmental systems perspective. School Psychology Review, 17(3), 407-417.

Polak, E. L., \& McCullough, M. E. (2006). Is gratitude an alternative to materialism? Journal of Happiness Studies, 7(2), 343-360.

Richardson, G. E., \& Waite, P. J. (2002). Mental health promotion through resilience and resiliency education. International Journal of Emergency Mental Health, 4(1), 65-75.

Rickinson, B. (1997). Evaluating the effectiveness of counselling intervention with final year undergraduates. Counselling Psychology Quarterly, 10(3), 271-285.

Rind, B., \& Bordia, P. (1995). Effect of server's - thank youll and personalization on restaurant tipping. Journal of Applied Social Psychology, 25, 745-751

Sacker, A., \& Schoon, I. (2007). Educational resilience in later life: Resources and assets in adolescence and return to education after leaving school at age 16. Social Science Research, 36(1), 873-896.

Seligman, M. E. P., Steen, T. A., Park, N., \& Peterson, C. (2005). Positive psychology progress: empirical validation of interventions. The American Psychologist, 60(5), 410-21.

Sheldon, K., \& Lyubomirsky, S. (2005). Achieving sustainable gains in happiness: Change your actions, not your circumstances. Journal of Happiness Studies, 7(1), 55-86.

Smith, G. (1999). Resilience concepts and findings: implications for family therapy. Journal of Family Therapy, 21, 154-158

Smokowski, P. R., Reynolds, A. J., \& Bezruczko, N. (1999). Resilience and protective factors in adolescence: An autobiographical perspective from disadvantaged youth. Journal of School Psychology, 37(4), 425-48.

Stallman, H. M. (2010). Psychological distress in university students: A comparison with general population data. Australian Psychologist, 45(4), 249-257

Tao, S., Dong, Q., Pratt, M. V., Hunsberger, B., \& Pancer, S. M. (2000). Social support: Relations to coping and adjustment during the transition to university in the people $\mathrm{S}$ republic of China. Journal of Adolescent Research, 15(1), 123-144.

Taylor, E. R. (2000). Making Resiliency Meaningful in the New Millennium. Retrieved from http://www. meaning.ca/pdf/2000proceedings elizabeth_taylor.

Wang, M. C., \& Gordon, E. W. (1994). Educational resilience in inner city America. Hillsdale, NJ, Erlbaum 
Wasonga T, Christman DE, Kilmer L (2003) Ethnicity, gender and age: Predicting resilience and academic achievement among urban high school students. American Secondary Education 32(1), 62-74.

Watkins, P.C. (2004). Gratitude and subjective well-being. In R.A. Emmons \& M.E. McCullough (Eds.), The psychology of gratitude (pp. 167-102). New York, NY: Oxford University Press.

Werner, E. E., \& Smith, R. S. (1992). Overcoming the odds: High risk children from birth to adulthood. Ithaca, NY: Cornell University.

Werner, E. (1993). Risk,resilience, and recovery. Perspective from the Kauai Longitudinal Study. 5(2), 503-515

Werner, E., \& Smith, R. (2001). Journeys from childhood to the midlife: Risk, resilience, and recovery. New York, NY: The New Press

Wilcox, P., Winn, S., \& Fyvie-Gauld, M. (2005). 'It was nothing to do with the university, it was just the people': The role of social support in the first year experience of higher education. Studies in Higher Education, 30(6), 707-722

Winter MG, Yaffe M 2000. First year student adjustment to university life as a function of relation-ship with parents. Journal of Adolescent Research, 15(2), 19-37.

Wolin, S. J., \& Wolin, S. (1993). The resilient self: How survivors of troubled families rise above adversity. New York: Villard Books.

Wood, A. M., Froh, J. J., \& Geraghty, A. W. A. (2010). Gratitude and well-being: a review and theoretical integration. Clinical Psychology Review, 30(7), 890-905.

Wood, A. M., Joseph, S., \& Linley, P. A. (2007). Coping Style As A Psychological Resource Of Grateful People. Journal of Social and Clinical Psychology, 26, 1108-1125.

Wood, A.M., Maltby, J., Gillet, R., Linley, P.A., \& Joseph,S. (2008). The Role of Gratitude inteh Development of Social Support, Stress, and Depression : Two Longitudinal Studies. Journal of Research in Personality, 42(2), 854-871 